\title{
Federalism without Federal Values? Austrian Citizens' Attitudes towards Federalism and their Effects on Political Culture
}

\section{by Peter Bußjäger}

Institute of Federalism, Austria

Email: peter.bussjaeger@foederalismus.at

\section{Abstract:}

In 2009, the Institute of Federalism launched an enquiry of Austrian citizens' federal values. The survey was carried out from February to April 2009 in cooperation with the Institute of Political Science of the University of Innsbruck.

The result of the survey "Federal Consciousness of Austrian Citizens" has confirmed the thesis that Austrian federalism is characterized by a paradox: On the one hand, citizens value the existing federal structure, but on the other hand they oppose competition among the Länder. They strongly prefer the current system of cooperative federalism with its mixed and intransparent structures.

Federalism in Austria faces the challenge to convince citizens of the values of differentiation among the legal systems which comprise this comparatively small country. It appears to be time for a re-construction of Austrian federalism by applying the concept of differentiated, innovative federalism.

Keywords: Austria, federalism, European Union, federation, Länder, uniformity of living conditions, political culture 


\section{About Federal Governance}

Federal Governance is an online graduate journal on theory and politics of federalism and multilevel governance. Its mandate is to engage the global federalism community and reach out to outstanding graduate students interested in federalism and multi-level governance. By providing a platform for graduate students to have early success in their careers, Federal Governance seeks to promote and sustain interest in federalism and multi-level governance research among graduate students. Allied with the Forum of Federations and founding partner, Institute of Intergovernmental Relations at Queen's University; Federal Governance aims to contribute to a global dialogue on federalism.

Co Chairs, Advisory Committee:

Publisher:

Managing Editor:

Associate Editors:
Rupak Chattopadhyay and Christian Leuprecht

Forum of Federations

(Rupak Chattopadhyay and Philip Gonzalez)

Dominic Heinz

Maria Bertel, Joshua Cerovski, Carey Doberstein, Eva-

Maria Maggi, Sean Müller, Eyene Okpanachi, Samir

Sharma and Victoria Tait

\section{Terms of Use}

Your use of this Federal Governance article indicates your acceptance of Federal Governance's Terms and Conditions of Use, available at www.federalgovernance.ca/terms. Federal Governance's Terms and Conditions of Use provides that you may use Federal Governance content only for personal, academic and non-commercial use. Each copy of any part of this Federal Governance article must contain the same copyright notice that appears on the screen or printed page of such transmission. 


\section{Introduction: "Federalism in Austria is something for the mind"}

In his 2004 paper Austria a Federation without Federalism? the Canadian researcher Jan Erk stated that

"the Austrian federation seems to work more as a unitary system because all political issues are set in a pan-Austrian frame of reference. This is because the federation lacks territorially based societal heterogeneity to sustain a principled commitment to federalism. Societal homogeneity induces a centralist political outlook at all levels of government which undermines the notion of self-rule in constituent units essential for federalism. (...) [T]he empirical evidence strongly suggests that the Austrian federation's centralist disposition stems from its social structure, not its formal constitution." (Erk 2004: 20)

Jan Erk does not stand alone with this assessment; even in Austria. In the context of the discussion about the reform of Austrian federalism, Ewald Wiederin characterized Austrian citizens' attitudes towards federalism as follows: "One is not a federalist when it comes to factual issues but for the mind." (Wiederin 2004: 58). This statement implies that federalism is deeply rooted in Austrian citizens' minds and that they value the existence of the nine Länder. Yet, Austrians are not particularly fond of asymmetric federalism which results in different laws and standards throughout the country. According to Wiederin Austrians prefer a unitary federation without federal competition among the Länder.

Peter Bußjäger argues that Austrian federalism is a matter of mentality (Bußjäger 2002: 149). According to Bußjäger, citizens approve unitary living conditions in the whole country while simultaneously supporting the notion that important matters of legislation remain within the jurisdiction of the Länder. Presently this paradox seems to shape Austrian federalism. But is it really true? Is there any empirical evidence that substantiates this thesis?

\footnotetext{
${ }^{1}$ „Föderalist ist man nicht in der Sache, sondern für das Gemüt.“
} 
1. A Survey on Austrian citizens' federal values: A research project conducted by the Institute of Federalism

\section{a. Introductory remarks on Austrian federalism}

Austria is a federation on the basis of the Federal Constitution (B-VG) from 1920. According to Art. 2 B-VG it consists of nine autonomous Länder. The Republic of Austria covers a territory of approximately $84,000 \mathrm{~km}^{2}$ and has 8.3 million inhabitants. In contrast to Germany, the USA, or Canada, Austria is a relatively small federation which can be compared with Belgium and Switzerland.

Austrian society is rather homogeneous in terms of religion (most Austrians are Catholics) and ethnic composition (there are only a few minorities like the Croats in Burgenland, or the Slovenians in Carinthia). The country's national language is German. Economic disparities among the Länder still exist, even though the former west-east economic divide appears to be vanishing.

All Länder have the same constitutional status with some exceptions like the capital Vienna, which is both a Land and a municipality (Pernthaler 2004: 459 - 465).

Austrian federalism is related to the historical identity of the Austrian Länder, which go back to medieval entities and have been part of the "Kronländer" of the AustrianHungarian Empire. The Länder played a leading role in the foundation of the $1^{\text {st }}$ Republic in 1918 (cf. Sturm 2005: 46 - 47; Pernthaler 1979: 19 - 33).

\section{b. Previous research}

There is little (scientific) research about the sentiments of Austrian citizens in regard to their emotional attachment vis-à-vis Austria in general or their Land or municipality of residence in particular. In 1991 surveys showed that 80 per cent view themselves "more as Austrians" and only four percent "first and foremost as Europeans". Until 2001 (six years after Austria's accession to the EU) the former figure dropped to 71 per cent, while the latter increased by eight percent (Plasser/Ulram 2002: 174). A relatively strong attachment to the Länder of residence could be observed in the western Länder of Salzburg, Tyrol and Vorarlberg. Länder symbols seem not to be very well-known. A 
representative survey in Vorarlberg carried out at the beginning of 2003 revealed that only 31 per cent of respondents were able to correctly describe the Land emblem. In turn, 75 per cent knew the Land colors (Ludwig Boltzmann Institut für sozialwissenschaftliche Regionalforschung 2003: 20 - 22).

The latest survey results concerning the emotional connection of Austrian citizens to the various levels of government go back to 2001 (see table 1) (Plasser/Ulram 2003: 433).

Table 1: Primary Emotional Attachment (2001) (in per cent)

\begin{tabular}{|c|c|c|c|c|}
\hline & $\begin{array}{l}\text { Hometown } \\
\text { or Region }\end{array}$ & Land & Austria & $\begin{array}{l}\text { Other Places } \\
\text { (Europe, } \\
\text { World etc.) }\end{array}$ \\
\hline Burgenland & 46 & 25 & 53 & 22 \\
\hline Carinthia & 37 & 29 & 45 & 17 \\
\hline Lower Austria & 45 & 15 & 56 & 12 \\
\hline Upper Austria & 51 & 18 & 46 & 14 \\
\hline Salzburg & 34 & 39 & 42 & 16 \\
\hline Styria & 39 & 26 & 47 & 14 \\
\hline Tyrol & 50 & 32 & 30 & 17 \\
\hline Vorarlberg & 34 & 36 & 37 & 30 \\
\hline Vienna & 15 & 32 & 54 & 20 \\
\hline Austria & 38 & 25 & 48 & 17 \\
\hline
\end{tabular}

With regard to the emotional attachment of Austrian citizens to European federalism, the following observation is interesting:

The Eurobarometer (2005: 9) survey revealed that 44 per cent of Austrians regard themselves as Austrians and will likely continue to do so in the near future, while another 44 per cent view themselves as Austrians or Europeans. Six percent consider themselves to be Europeans and Austrians while yet another two percent regard themselves to be Europeans only. Trust in the EU differs among the Länder. While in western Austria trust in the EU is generally higher e.g. the Burgenland ranks among the Länder where support is relatively low. This is particularly interesting, given that Burgenland has profited enormously from EU structural funds due to its status as a former Objective 1 Region.

c. Research conducted by the Institute of Federalism 
In 2009, the Institute of Federalism launched an enquiry of Austrian citizens' federal values. The survey was carried out from February to April 2009 in cooperation with the Institute of Political Science of the University of Innsbruck (see Bußjäger/Karlhofer/Pallaver 2010). So far, it has been the most extensive poll on federal values in Austria and was based on the Bertelsmann Foundation's study Bürger und Föderalismus which was conducted in Germany in 2008 (Bertelsmann Stiftung 2008). This allowed for an interesting comparison between Austrian and German poll results.

\section{Results of the survey conducted by the Institute of Federalism}

\section{a. Emotional attachment to the Länder}

In public discussion, "Europe" is used as an argument against federalism (in Austria): The involvement of the Austrian federation in the European multi-level system raises the question of whether, as a comparatively small member state, the federal system should be maintained. Even though the abolishment of federalism is not the main topic in the present debate, the fact that both the Länder as well as the national government have lost competencies and autonomy due to EU-membership, is used as an argument for further centralization. This is an important paradigm shift vis-à-vis reform efforts in the years preceding the accession to the EU (structural reform of competencies).

In the framework of the institute's project the following statement was put forward:

"We do not need the Länder anymore, because the EU und the Federation are dealing with the really important matters."

The results are as follows:

\section{Table 2a: Acceptance of Länder}

"We do not need the Länder anymore"
Burgenland
Carinthia
Lower Austria
Upper Austria
Salzburg

rather in favor $25.5 \%$ $16.8 \%$ $16.2 \%$ $15.5 \%$ $26.1 \%$
Rather against $74.5 \%$ $83.2 \%$ $83.8 \%$ $84.5 \%$ $73.9 \%$ 


$\begin{array}{lll}\text { Styria } & 26.7 \% & 73.3 \% \\ \text { Tyrol } & 18.5 \% & 81.5 \% \\ \text { Vorarlberg } & 14.7 \% & 85.3 \% \\ \text { Vienna } & 25.2 \% & 74.8 \% \\ \text { Austria } & 20.7 \% & 79.3 \%\end{array}$

It is of special interest to compare the results of this survey with the ones from Germany. The acceptance of the Austrian Länder is in the federal average 79.3 per cent. This appears to be very high; in any case higher than in Germany (75\%).

This result suggests that the existence of the Länder is deeply rooted in the identity and consciousness of the citizens.

Differences among the citizens in the Länder are relatively small: The degree of acceptance is highest in Upper Austria and Vorarlberg with 84.1 percent or 83.6 percent respectively and lowest in Salzburg (73.0\%) and Styria (74.1\%). In the past it has often been argued that there is a west-east divide in federal values. The results now show no significant difference between the Austrian Länder. Not even the capital Vienna differs considerably $(74.4 \%)$.

The project also inquired about citizens' emotional attachment to the Länder compared with other levels of the state.

In 2009 the Austrians answered this question as follows:

Table 2b: Emotional connection

\begin{tabular}{lrrrr}
$\begin{array}{l}\text { Emotional } \\
\text { detachment }\end{array}$ & \multicolumn{1}{l}{$\begin{array}{l}\text { City or } \\
\text { Municipality }\end{array}$} & Land & Austria & Europe \\
\hline Tyrol & $22.0 \%$ & $42.7 \%$ & $20.0 \%$ & $15.3 \%$ \\
Carinthia & $19.3 \%$ & $35.1 \%$ & $27.2 \%$ & $18.4 \%$ \\
Vorarlberg & $22.1 \%$ & $29.4 \%$ & $27.9 \%$ & $20.6 \%$ \\
Upper Austria & $22.9 \%$ & $19.4 \%$ & $46.1 \%$ & $11.6 \%$ \\
Lower Austria & $20.7 \%$ & $19.3 \%$ & $40.0 \%$ & $20.0 \%$ \\
Styria & $19.2 \%$ & $16.0 \%$ & $47.9 \%$ & $16.9 \%$ \\
Burgenland & $18.9 \%$ & $15.1 \%$ & $47.2 \%$ & $18.9 \%$ \\
Salzburg & $24.7 \%$ & $9.7 \%$ & $41.9 \%$ & $23.7 \%$ \\
Vienna & $17.4 \%$ & $6.3 \%$ & $46.1 \%$ & $30.3 \%$ \\
Austria & $20.4 \%$ & $19.3 \%$ & $40.3 \%$ & $19.9 \%$ \\
& & & & \\
Austria $\quad$ except & & & & \\
Vienna & $\mathbf{2 1 . 2 \%}$ & $\mathbf{2 2 . 7 \%}$ & $\mathbf{3 8 . 9} \%$ & $\mathbf{1 7 . 3 \%}$
\end{tabular}

As it is doubtful whether the citizens of Vienna can distinguish their respective emotional connections with Vienna as a Land and Vienna as a municipality, results 
have been adjusted (table $2 \mathrm{~b}$ ). As can be seen above, the overall result changes when leaving out the of data for Vienna.

The opinion poll conducted by the Institute of Federalism exhibited significant differences in comparison to the results of Plasser and Ulram. Notably, we found support for the "emancipation" of the EU. Furthermore, identification with all other levels of government have significantly decreased; both, with regard to the local level and clearly also with regard to the Federation. The acceptance of the Länder has not been changed considerably according to our results.

Table 2c depicts the respective results for Germany.

Table 2c: Emotional attachment (Germany 2008)

\begin{tabular}{|l|r|}
\hline City/Municipality & $39 \%$ \\
\hline Land & $11 \%$ \\
\hline Germany & $32 \%$ \\
\hline Europe & $14 \%$ \\
\hline All levels & $2 \%$ \\
\hline No level & $2 \%$ \\
\hline
\end{tabular}

With regard to Germany, the following differences appear to be noteworthy: In comparison with Germany, Austrians have a stronger feeling of emotional attachment as far as the Länder are concerned. With regard to the local level, this sentiment is significantly weaker. Identification with Europe but also with Austria is significantly stronger.

One reason for this strong emotional attachment to the Länder could be seen in the fact that 66 percent of the Austrian people still live in the Land in which they were born. This also holds true for Germany (70\%) even though one needs to consider that the German Land Bavaria alone covers the same territory as the entire country of Austria! 
Table 2d: Percentage of people who still live in the Land in which they were born

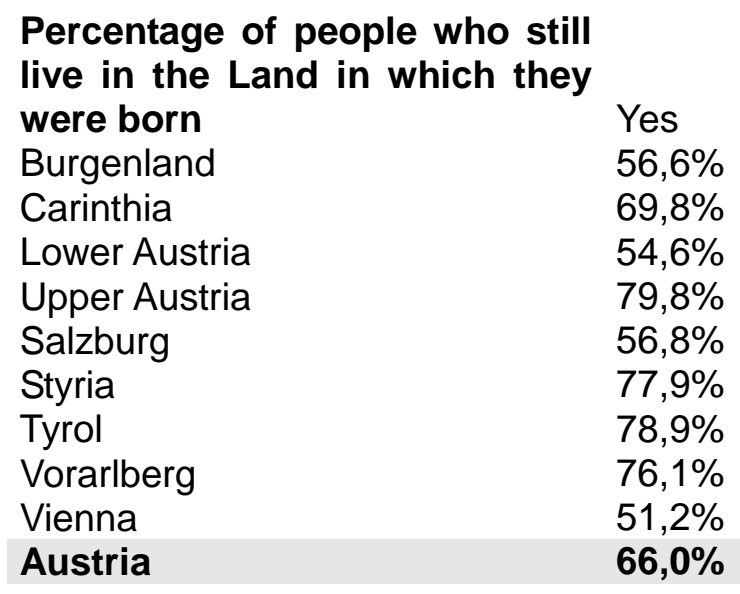

b. Appreciation of work of the Länder

As a further aspect of the research project respondents were asked how much they appreciate the effort of various levels of government (EU, Federation, Länder, Cities and Municipalities).

Table 3: Appreciation of effort of different levels of government

"Appreciation of effort of..."

EU Federation Länder Cities and

Mean 3.2

$\begin{array}{lll}3.2 & 2.9 & 2.4\end{array}$

$\begin{array}{llll}\text { Standard deviation } & 0.9 & 0.9 & 1.0\end{array}$

EU Federation Länder Cities and

Municipalities

Very Good

Good

Satisfying

Sufficient

Insufficient

Data in \%
2.8

17.9

48.9

19.9

10.5

3.7

15.5

46.5

25.6

46.7

16.4

9.1

3.3
20.9

41.1

25.0

9.9

3.0 
This result is not surprising: lower levels of government, such as municipalities and Länder, are closer to the citizens and therefore have an advantage in making their work visible. This result is similar to that obtained by a survey carried out on behalf of the Landtag of Vorarlberg in 2008. The arithmetic mean of the appreciation of the Länder's work with a grade of 2.4 is close to those of the municipalities (2.3). In comparison with Germany, this shows a high appreciation of the effort of the Länder (in Germany 3.0 for the Länder, 2.8 for the municipalities).

The significant difference vis-à-vis the Federation is striking (2.9), even though it is still considered to perform better than its German counterpart (3.4). The EU's work is graded with 3.2 in Austria as opposed to 3.4 in Germany and is therefore also better. This comes as a surprise since the Eurobarometer data usually ranks Austrians higher than Germans with regard to EU scepticism.

One further explanation of the positive appraisal of the Länder's work is that at Länder level government activities seem to appear more continiously in contrast to government activities on the federal level. The fact that Austria had four different federal governments over the last ten years may also contribute to this notion.

\section{c. Austrians wish to keep the status quo}

Furthermore, respondents were asked which level of governance should have more influence in the future. The results did not vary much:

Table 4: Which level of governance should play a more important role in the future

$\begin{array}{lrrrr}\begin{array}{l}\text { "More important } \\ \text { for..." }\end{array} & \text { EU } & \text { Federation } & \text { Länder } & \text { Cities/Municipalities } \\ \text { Burgenland } & 52,9 \% & 72,0 \% & 64,7 \% & 73,5 \% \\ \text { Carinthia } & 59,8 \% & 70,4 \% & 64,2 \% & 72,4 \% \\ \text { Lower Austria } & 54,5 \% & 72,7 \% & 59,4 \% & 66,7 \% \\ \text { Upper Austria } & 56,7 \% & 70,6 \% & 63,2 \% & 77,6 \% \\ \text { Salzburg } & 64,4 \% & 66,7 \% & 61,8 \% & 72,7 \% \\ \text { Styria } & 61,0 \% & 65,9 \% & 55,5 \% & 69,4 \% \\ \text { Tyrol } & 62,0 \% & 62,1 \% & 73,9 \% & 74,6 \%\end{array}$




$\begin{array}{lllll}\text { Vorarlberg } & 62,1 \% & 63,1 \% & 75,4 \% & 65,2 \% \\ \text { Vienna } & 66,7 \% & 62,9 \% & 42,0 \% & 62,4 \% \\ \text { Austria } & \mathbf{6 0 , 3 \%} & \mathbf{6 7 , 4} \% & \mathbf{5 8 , 7} \% & \mathbf{6 9 , 7 \%}\end{array}$

Obviously, citizens wish that cities and municipalities, which are the levels of governance closest to them, should attain considerably more influence and power $(69.7 \%)$.

There is a majority of 58.7 per cent wishing to strengthen role of the Länder. However, there are more citizens prefering to strengthen the Federation (67.0\%). Strengthening the role of the EU ranks lowest with 57.9 per cent.

It can be argued that the federal level is appreciated more in times of crisis. Yet, the relatively low differences in the assessment indicates insecurity of the population and suggests that people tend to be averse to change. Even though the majority seems to prefer a strengthening of all levels, the result can be considered as a plea for the status quo. Admittedly: At municipal level the number of people who desire the strengthening of the municipalities is especially high.

The results are very similar to the German ones. Regarding both Germany and Austria, it holds true that the strengthening of the Länder level is not the issue considered most important in the context of Europeanisation.

It is remarkable that the European Union ranks first with regard to the level at which uniformity of living conditions ("einheitliche Lebensbedingungen") should be generated (37.2\%). With only a marginal difference the Federation ranks second (35.7\%). Cities and municipalities trail far behind (13.7\%). The Länder bring up the rear (13.4\%). In Germany 46 to 59 per cent prefer the Federation as the level at which uniform living conditions should be achieved. The German Länder rank similar with their Austrian counterparts.

Table 5: At which level should living conditions be similar?

"Living conditions
should be similar on
the level of the..." EU City/




$\begin{array}{lrrrr}\text { Burgenland } & 36.5 \% & 42.3 \% & 11.5 \% & 9.6 \% \\ \text { Carinthia } & 32.7 \% & 32.7 \% & 15.9 \% & 18.6 \% \\ \text { Lower Austria } & 33.5 \% & 40.4 \% & 10.7 \% & 15.4 \% \\ \text { Upper Austria } & 35.7 \% & 37.3 \% & 16.9 \% & 10.0 \% \\ \text { Salzburg } & 40.2 \% & 37.0 \% & 10.9 \% & 12.0 \% \\ \text { Styria } & 37.5 \% & 31.5 \% & 13.9 \% & 17.1 \% \\ \text { Tyrol } & 31.2 \% & 38.3 \% & 18.4 \% & 12.1 \% \\ \text { Vorarlberg } & 37.3 \% & 29.9 \% & 19.4 \% & 13.4 \% \\ \text { Vienna } & 45.0 \% & 32.7 \% & 9.3 \% & 13.0 \% \\ \text { Austria } & \mathbf{3 7 . 2 \%} & \mathbf{3 5 . 7} \% & \mathbf{1 3 . 4 \%} & \mathbf{1 3 . 7 \%}\end{array}$

It is doubtful that these poll results provide an argument for centralisation on the federal level. It might be rather supposed that the Austrians do not oppose comparable standards in Europe. The results also express a readiness for solidarity.

\section{d. Demand for active role of the Länder}

The tendency of preserving the status quo and the reluctance towards change is supported by the following results: While an active role of the Länder is perceived as veto politics, the majority of Austrians are not convinced that the Länder interfere excessively.

The statement "The Länder interfere too strongly in federal politics" is rejected by a total of 73.1 percent.

Table 6: The Länder interfere too strongly in federal politics

$\begin{array}{lrr}\begin{array}{l}\text { "The Länder interfere } \\ \text { (v.s.) too strongly in } \\ \text { federal politics." }\end{array} & \begin{array}{c}\text { Rather } \\ \text { acceptance }\end{array} & \begin{array}{c}\text { Rather } \\ \text { rejection }\end{array} \\ \text { Burgenland } & 34.6 \% & 65.4 \% \\ \text { Carinthia } & 28.4 \% & 71.6 \% \\ \text { Lower Austria } & 33.2 \% & 66.8 \% \\ \text { Upper Austria } & 21.0 \% & 79.0 \% \\ \text { Salzburg } & 34.5 \% & 65.5 \% \\ \text { Styria } & 36.6 \% & 63.4 \% \\ \text { Tyrol } & 16.2 \% & 83.8 \% \\ \text { Vorarlberg } & 13.4 \% & 86.6 \% \\ \text { Vienna } & 37.6 \% & 62.4 \% \\ \text { Austria } & \mathbf{2 9 . 8 \%} & \mathbf{7 0 . 2} \%\end{array}$


More than two thirds of the population do not share the opinion that the Länder interfere too strongly in federal politics. Protection of interests vis-à-vis the federal level as practiced by the conference of Land governors for example, is appreciated by Austrians. It can be inferred that the much-criticised activities of the land parliaments (Landtage), to interfere beyond their legislative competencies and the control of the land executive in federal matters by submitting resolutions to the Federation, is supported by a majority of the population. The citizens wish that the Land governor and the President of the Landtag serve as their mouthpiece vis-àvis other levels of government.

These findings are also confirmed by the answers given to the following question:

"The Länder should be more strongly represented in Brussels."

A total of $61.2 \%$ of Austrians agree with this statement. Conversely the European level is considered to be predominantly within the jurisdiction of the Federation. Yet, people are still in support of an active representation of their interests by the representatives of the Länder. Which institutions of the EU were considered to be the best points of contact was left open in the survey.

\section{Table 7: The Länder should be more strongly represented in Brussels}

$\begin{array}{lrr}\begin{array}{l}\text { “The Länder should be more } \\ \text { strongly represented in } \\ \text { Brussels." }\end{array} & \begin{array}{c}\text { Rather } \\ \text { Acceptance }\end{array} & \begin{array}{c}\text { Rather } \\ \text { rejection }\end{array} \\ \text { Burgenland } & 64,2 \% & 35,8 \% \\ \text { Carinthia } & 66,4 \% & 33,6 \% \\ \text { Lower Austria } & 57,2 \% & 42,8 \% \\ \text { Upper Austria } & 54,2 \% & 45,8 \% \\ \text { Salzburg } & 67,0 \% & 33,0 \% \\ \text { Styria } & 58,8 \% & 41,2 \% \\ \text { Tyrol } & 72,2 \% & 27,8 \% \\ \text { Vorarlberg } & 67,6 \% & 32,4 \% \\ \text { Vienna } & 41,5 \% & 58,5 \% \\ \text { Austria } & \mathbf{5 7 , 1} \% & \mathbf{4 2 , 9 \%}\end{array}$


There seems to be a consensus among citizens that the Länder should have their own representations. At the same time this does not exclude a closer cooperation among the Länder in Brussels.

In contrast to Germany, no conflict is perceived between Federation and Länder with regard to EU matters. Even if such conflicts did exist, they never reached the public. Though, an important topic of Germany's Federalism Reform was the notion that Germany should speak in Brussels "with one voice“. This problem has never been prominent in Austria. The Länder have always accepted the dominance of the Federation at the European level, especially since the cooperation between Federation and Länder has so far worked fairly well in this regard.

\section{e. Support of co-operative federalism - refusal of competitive federalism} Juridical differentiations are essential elements of federal systems. Nine different jurisdictions only make sense if they have legal differences. In contrast uniform and harmonised or standardised land law delegitimizes federalism.

In both Germany and Austria the trend towards a unitary federation has been observed for many years. In a unitary federation differentiation is levelled to a great extent while the federal institutions are preserved.

Some aspects of competitive federalism were introduced to the unitary federal state. In competitive federalism subnational entities appear as independent actors and compete as locations for enterprises, jobs, settlement-willing citizens with suitable tax achievement, or educational institutions. They compete with the instrument which is available to them, namely the right.

A further strand of literature is devoted to questions of federal cohesion as well as of competitive federalism. This resulted in the relatively high refusal of competition and stressed solidarity in the federal state through solidarity of the subnational entities.

While 88.1 per cent of the population agrees with the statement "The Länder should rather close ranks and not confront each other in competition.", only 9.3 per cent reject it. 
Table 8: The Länder should rather close ranks and not confront each other in competition

"The Länder should
rather close ranks..."
Burgenland
Carinthia
Lower Austria
Upper Austria
Salzburg
Styria
Tyrol
Vorarlberg
Vienna

Austria

$\begin{array}{rr}\begin{array}{c}\text { Rather } \\ \text { Acceptance }\end{array} & \begin{array}{r}\text { Rather } \\ \text { rejection }\end{array} \\ 82.7 \% & 17.3 \% \\ 87.7 \% & 12.3 \% \\ 88.1 \% & 11.9 \% \\ 89.2 \% & 10.8 \% \\ 87.2 \% & 12.8 \% \\ 87.0 \% & 13.0 \% \\ 917 \% & 8.3 \% \\ 82.1 \% & 17.9 \% \\ 88.9 \% & 11.1 \% \\ \mathbf{8 8 . 1} \% & \mathbf{1 1 . 9} \%\end{array}$

The high support for solidarity among the Länder does not come by surprise. It corresponds with the results obtained among the German population.

Common action is not only preferred among the Länder but also with regard to the federal level. The statement „With big challenges, such as climate change or health reform, I wish for a common action of Federation and Länder" is supported by 97 per cent while only three per cent do not call for unified action.

Table 9: With big challenges, such as climate change or health reform, I wish for common action of Federation and Länder

$\begin{array}{lll}\text { "Big challenges..." } & \begin{array}{l}\text { Rather } \\ \text { Acceptance }\end{array} & \begin{array}{l}\text { Rather } \\ \text { Rejection }\end{array} \\ \text { Burgenland } & 90,6 \% & 9,4 \% \\ \text { Carinthia } & 90,6 \% & 9,4 \% \\ \text { Lower Austria } & 97,1 \% & 2,9 \% \\ \text { Upper Austria } & 98,0 \% & 2,0 \% \\ \text { Salzburg } & 97,8 \% & 2,2 \% \\ \text { Styria } & 95,9 \% & 4,1 \% \\ \text { Tyrol } & 98,6 \% & 1,4 \% \\ \text { Vorarlberg } & 94,2 \% & 5,8 \% \\ \text { Vienna } & 97,8 \% & 2,2 \% \\ \text { Austria } & 96,6 \% & 3,4 \%\end{array}$


Again, this result corresponds with the essential preferences outlined in the German survey. However, this also means a refusal of unilateral action by the Federation. People value cooperative federalism in important matters of politics.

The population's demand for competition in different areas is of special interest. A distinction was made between administrative reform, education, health and taxes. Particularly in the area of fiscal federalism, a rejection of competition is recognizebale.

Table 10: I wish for competition in the following areas

\begin{tabular}{|c|c|c|c|c|c|c|}
\hline areas of competition & 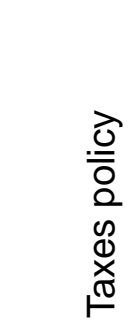 & 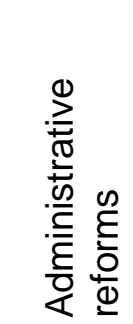 & 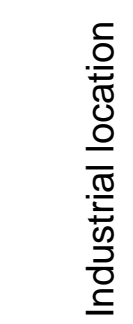 & 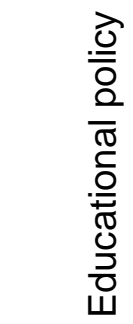 & 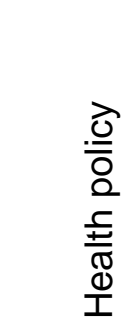 & 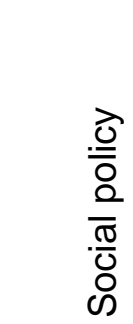 \\
\hline Burgenland & $17.0 \%$ & $31.5 \%$ & $42.6 \overline{\%}$ & $35.8 \%$ & $22.6 \%$ & $17.0 \%$ \\
\hline Carinthia & $16.9 \%$ & $34.2 \%$ & $42.7 \%$ & $35.9 \%$ & $29.9 \%$ & $27.1 \%$ \\
\hline Lower Austria & $16.1 \%$ & $28.2 \%$ & $40.3 \%$ & $28.5 \%$ & $19.9 \%$ & $20.1 \%$ \\
\hline Upper Austria & $21.4 \%$ & $34.6 \%$ & $42.7 \%$ & $35.4 \%$ & $34.2 \%$ & $29.4 \%$ \\
\hline Salzburg & $21.9 \%$ & $38.9 \%$ & $26.3 \%$ & $41.7 \%$ & $37.5 \%$ & $35.8 \%$ \\
\hline Styria & $17.6 \%$ & $27.5 \%$ & $22.3 \%$ & $27.5 \%$ & $24.0 \%$ & $17.6 \%$ \\
\hline Tyrol & $34.6 \%$ & $49.0 \%$ & $53.3 \%$ & $43.1 \%$ & $35.3 \%$ & $35.3 \%$ \\
\hline Vorarlberg & $19.7 \%$ & $18.3 \%$ & $40.8 \%$ & $26.8 \%$ & $21.1 \%$ & $15.5 \%$ \\
\hline Vienna & $19.8 \%$ & $46.3 \%$ & $51.5 \%$ & $39.6 \%$ & $25.6 \%$ & $22.9 \%$ \\
\hline Austria & $20.3 \%$ & $35.5 \%$ & $41.1 \%$ & $34.6 \%$ & $27.4 \%$ & $24.4 \%$ \\
\hline
\end{tabular}

From table 10 one can conclude the refusal of a strictly competitive order (in respect of Germany see also Köcher 2012: 759 - 760). This does not oppose the idea of innovative federalism since the traditionally strong co-operative element in Austrian federalism might be indisputable because of its long heritage.

f. In which areas should money be invested / be saved?

Hospitals, social welfare and residential construction are cost-intensive competencies of the Austrian Länder. The survey has also clarified in which areas citizens are willing to invest and where expenses should be lowered. 
Table 11: Use of additional tax revenues

Additional tax revenues

\begin{tabular}{|c|c|c|c|c|c|c|}
\hline & $\begin{array}{l}\text { Reducing } \\
\text { debt }\end{array}$ & Social benefits & $\begin{array}{l}\text { Educatio } \\
\mathrm{n}\end{array}$ & $\begin{array}{l}\text { Infrastructur } \\
\mathrm{e}\end{array}$ & $\begin{array}{l}\text { Health } \\
\text { system }\end{array}$ & $\begin{array}{l}\text { Reducing } \\
\text { taxes }\end{array}$ \\
\hline Mean & 2.6 & 2.6 & 1.7 & 2.4 & 2.1 & 2,9 \\
\hline Standard deviation & 1.3 & 1.3 & 1.0 & 1.0 & 1.1 & 1,2 \\
\hline
\end{tabular}

$\begin{array}{lllllll} & \begin{array}{l}\text { Reducing } \\ \text { debt }\end{array} & \text { Social benefits } & \begin{array}{l}\text { Educatio } \\ \mathrm{n}\end{array} & \begin{array}{l}\text { Infrastructur } \\ \text { e }\end{array} & \begin{array}{l}\text { Health } \\ \text { system }\end{array} & \begin{array}{l}\text { Reducing } \\ \text { taxes }\end{array} \\ \text { yes, in any case } & 24.0 & 22.2 & 56.6 & 21.3 & 37.1 & 14.2 \\ 2 & 22.5 & 29.0 & 27.6 & 32.5 & 30.8 & 22.0 \\ 3 & 32.2 & 24.9 & 10.3 & 32.0 & 21.6 & 36.4 \\ 4 & 10.2 & 12.8 & 2.4 & 10.8 & 6.3 & 15.4 \\ \text { No, in no case } & 11.1 & 11.0 & 3.0 & 3.4 & 4.1 & 12.0 \\ \text { data in \% } & & & & & & \end{array}$

Table 12: Acceptance of expenditure cuts

\section{Expenditure cuts}

$\begin{array}{llllll} & \text { Defense } & \begin{array}{l}\text { Economic } \\ \text { policy }\end{array} & \begin{array}{l}\text { Educational } \\ \text { system }\end{array} & \text { Health system } & \begin{array}{l}\text { Administr } \\ \text { ation }\end{array} \\ \text { Mean } & 2.7 & 3.2 & 4.4 & 4.2 & 2.0 \\ \text { Standard Deviation } & 1.5 & 1.2 & 1.1 & 1.2 & 1.1\end{array}$

$\begin{array}{llllll} & \text { Defense } & \begin{array}{l}\text { Economic } \\ \text { policy }\end{array} & \begin{array}{l}\text { Educational } \\ \text { system }\end{array} & \text { Health system } & \begin{array}{l}\text { Administr } \\ \text { ation }\end{array} \\ \text { yes, in any case } & 30.3 & 8.9 & 3.9 & 5.4 & 42.8 \\ 2 & 17.3 & 20.6 & 4.8 & 6.1 & 27.6 \\ 3 & 23.0 & 31.6 & 7.5 & 11.3 & 21.5 \\ 4 & 11.8 & 19.6 & 15.1 & 17.7 & 5.1 \\ \text { no, in no case } & 17.6 & 19.3 & 68.7 & 59.5 & 3.0\end{array}$

From these examples one can see that the population supports issues in areas of Land competences (health service, training system) and rejects expenditure cuts. In contrast to this finding, as was to be expected, there is much acceptance for expenditure cuts in the area of public administration. 


\section{Federal values and political culture}

Cooperation and coordination are the main features of Austrian federalism. Competitive federalism is mostly rejected, both by political leaders and citizens. Homogeneous living standards in various fields of legislation are demanded by mass media and political leaders. One example is the present debate about uniform standards of social aid, which falls into the legislative and administrative domain of the Länder across the entire country. Uniform standards are demanded by nearly everyone in Austria: political parties, NGOs, civil society. As a consequence this exerts considerable pressure on the Länder with regard to the coordination of their activities.

In further consequence the use of public law-contracts according to Art. 15a B-VG both between the Federation and the Länder as among the Länder themselves is growing. One of the most important contracts are the "Mindestsicherungsvereinbarung" (an agreement on uniform standards of social aid) and the Austrian Stability Pact. The latter contract includes Federation, Länder as well as Cities and Municipalities in order to implement the obligations resulting from the European Fiscal Pact in internal Austrian law.

Another, maybe even more important contract is intended to regulate the financing of matters of health care, especially hospitals in Austria. This contract between the Federation and the Länder is still (August 2012) in elaboration. The working program of the current Federal Government depends in various parts on cooperation with the Länder (Bußjäger 2009: 144 - 145).

The survey of the Institute of Federalism shows that political culture and federal values of Austrian citizens are clearly linked and depend on each other. The intensity of cooperation and coordination between all levels of government in Austria finds its confirmation in the attitudes of the Austrian citizens. Another key feature of Austrian federalism is skepticism against competitive federalism which culminates in a clear rejection of taxation autonomy as a typical element of competitive federalism. In the present debate, representatives of the Federation are calling for more taxation autonomy on Land level. Up to now, a majority of the political leaders of the Länder have 
opposed this project. The results of the survey might suggest the following question: Why change a system where everybody wants to preserve the status quo?

The response to this question is that stagnation is always hazardous as it neglects the need for modernizing the federal system. Moreover long term unitarian and cooperative federalism are endangering the autonomy of the Länder and are undermining the idea of federalism.

However, there is a third way beyond unitarianism and cooperative federalism: the concept of innovative or learning-federalism. According to this notion, differentiation among the Länder does not primarily work by promoting competition but rather in the sense of a system of entities in which the states learn from each other and may adopt solutions that have been successful elsewhere. Promoting innovative federalism will be a future challenge, if the Länder want to liberate themselves from the pressure of uniform standards.

\section{Summary}

The result of the survey "Federal Consciousness of Austrian Citizens" has confirmed the thesis that Austrian federalism is characterized by a paradox: On the one hand, citizens value the existing federal structure, but on the other hand they oppose competition among the Länder. They strongly prefer the current system of cooperative federalism with its mixed and intransparent structures.

Federalism in Austria faces the challenge to convince citizens of the values of differentiation among the legal systems which comprise this comparatively small country. One of the main problems might be seen in the fact that political leaders in the Länder are not willing to take over more autonomy and more responsibility for their own decisions. Politicians of all levels of government believe in cooperative federalism with all its consequences.

It appears to be time for a re-construction of Austrian federalism by applying the concept of differentiated, innovative federalism. This, however, seems to require the change of political leaders' and citizens' minds alike. 


\section{References}

[1] Bertelsmann Stiftung, 2008, Bürger und Föderalismus, Gütersloh.

[2] Boltzmann, Ludwig, Institut für sozialwissenschaftliche Regionalforschung Bregenz, 2003, Vorarlberger Landessymbole im Meinungsbild der Bevölkerung. Bregenz. Internet: http://www.vorarlberg.at/pdf/meinungsumfrage vorarlber.pdf.

[3] Bußjäger, Peter, 2002, "Der sklerotische Bundesstaat”, Zeitschrift für Politik 2002/2, pp. $149-170$.

[4] Bußjäger, Peter, 2009, "'Change“ auf Österreichisch: Föderalistische Bemerkungen zum Regierungsprogramm der SPÖ-ÖVP-Koalition vom November 2008“, in: Bildungsprotokolle, Volume 17, ed. Kärntner Verwaltungsakademie, Klagenfurt, pp. 135 - 149.

[5] Bußjäger, Peter, Karlhofer, Ferdinand and Pallaver, Günther, 2010, Föderalistisches Bewusstsein in Österreich. Regionale Identitätsbildung und Einstellung der Bevölkerung zum Föderalismus, Vienna: Braumüller.

[6] Erk, Jan, 2004, "Austria: A Federation without Federalism?", Publius 2004/1, p. 1 20.

[7] Eurobarometer, 2005, Standard Eurobarometer 64. National Report: Austria (Fieldwork: October-November 2005). Publication: December 2005. Internet: http://www.europa.eu.int/comm/public opinion/archives/eb/eb64/eb64 at nat.pdf.

[8] Köcher, Renate, 2012, „Föderalismus im Spiegel der Demoskopie“ in Handbuch Föderalismus - Föderalismus als demokratische Rechtsordnung und Rechtskultur in Deutschland, Europa und der Welt, Volume III, ed. Ines Härtel, Springer, Heidelberg.

[9] Pernthaler, Peter, 1979, Die Staatsgründungsakte der österreichischen Bundesländer, Braumüller, Vienna.

[10] Pernthaler, Peter, 2004, Österreichisches Bundesstaatsrecht. Verlag Österreich, Vienna.

[11] Plasser, Fritz and Ulram, Peter A., 2002, Das österreichische Politikverständnis: Von der Konsens- zur Konfliktkultur?, WUV Universitätsverlag, Vienna.

[12] Plasser, Fritz and Ulram, Peter A., 2003, „Regionale Mentalitätsdifferenzen in Österreich: Empirische Sondierungen" in Der Bund und die Länder: Über Dominanz, Kooperation und Konflikte im österreichischen Bundesstaat, ed. Herbert Dachs, Böhlau Verlag, Vienna, pp. 421 - 440.

[13] Sturm, Roland, 2005, "Austria" in Handbook of Federal Countries 2005, ed. Ann L. Griffiths, McGill-Queen's University Press, Montreal \& Kingston/London/Ithaca.

[14] Wiederin, Ewald 2004, "Bundesstaat neu" in Der Österreich-Konvent. Zwischenbilanz und Perspektiven, ed. Österreichische Juristenkommission. Wien Graz, pp. $49-77$. 